\title{
Current Trends in Critical Discourse Studies of Textbooks: A Look at Selected Literature
}

\author{
Christopher Smith \\ Carleton University \\ Jaffer Sheyholislami \\ Carleton University
}

\begin{abstract}
Critical Discourse Studies (CDS) has increasingly served to examine the content of textbooks. Given momentum by critical social inquiry pertaining to textbook content, this study looks at peer-reviewed literature drawn from three scholarly databases (JSTOR, ERIC, and SAGE; cross-referenced with searches on Google Scholar) that use CDS for those investigations. Reviewing the selected literature, this study asks: What are the most represented approaches of CDS used for examining textbooks? What contextual themes appear to draw the most attention? In what fields of study are the examined textbooks situated? How do these emergent themes appear to be connected? What areas of research appear lacking in the collected literature? The findings illustrate that, while the methods of CDS and types of textbooks examined are diverse, the lion's share of contextual attention and critical utility appears to be given to foundational approaches to CDS and textbooks used for English language teaching. Further research directions on textbooks from a CDS perspective are discussed.
\end{abstract}

\section{Résumé}

Les Études Critiques du Discours (ÉCD) ont de plus en plus servi à examiner le contenu des manuels scolaires. Compte tenu de l'élan donné par l'enquête sociale critique concernant le contenu des manuels, cette étude examine la littérature évaluée par des pairs tirée de trois bases de données savantes (JSTOR, ERIC et SAGE ; croisées avec des recherches sur Google Scholar) qui utilisent ÉDC pour ces enquêtes. Passant en revue la littérature sélectionnée, cette étude pose les questions suivantes: Quelles sapproches de ÉDC utilisées pour examiner les manuels sont les plus représentées? Quels thèmes contextuels semblent attirer le plus d'attention? Dans quels domaines d'études se situent les manuels examinés ? Comment ces thèmes émergents semblent-ils être connectés ? Quels domaines de recherche semblent manquer dans la littérature collectée ? Les résultats montrent que, bien que les méthodes de CDS et les types de manuels examinés soient divers, la majorité de l'attention contextuelle et de l'utilité critique semble être accordée aux approches fondamentales des CDS et des manuels scolaires utilisés pour l'enseignement de l'anglais. D'autres directions de recherche sur les manuels scolaires du point de vue des ÉDC sont discutées. 


\section{Current trends in Critical Discourse Studies of Textbooks: A Look at Selected Literature}

For Foucault (2003), the institution of education in any society is a "management of populations" (Ball, 2012, p. 6), where power organizes, establishes, divides, classifies, chooses and produces social realities in that system (Ball, 2012; see also Gramsci \& Buttigieg, 1991). Foucault's (2003) argument about education and the formation of social realities identifies institutional frameworks as less than democratic and more about social control that begins at the primary level (Sharp et al., 2017) because they serve as an ideological apparatus of the state (Althusser, 2001; Youdell, 2006). If we acquiesce to arguments that education is a form of state, or dominant groups, sponsored indoctrination (Althusser, 2001; Bourdieu, 1973), then textbooks, as artifacts of that sponsorship, are understandably featured in a wide array of interdisciplinary studies that draw attention to their hegemonic discourses.

Textbooks are uniquely positioned to shape the values, knowledge, and alignments of subjectivity in their consumers (Fuchs \& Bock, 2018; Macgilchrist, 2017) because they represent a tactile promise of investment in knowledge. That perceived investment by consumers of textbooks imparts a measure of trust in the contents and the educators who negotiate its content (Giroux, 1988; Shor, 1992). Textbooks, therefore, represent a kind of legal tender for educational services because they carry an implicit, institutional endorsement. Such endorsement validates what social norms textbooks may convey (Thoma, 2017) as required truths for the procurement of knowledge. However, can knowledge as an implied commodity exist without power and/or ideology? Van Dijk (2011) insists that in textbooks, what passes for knowledge is often ideologically founded.

While there is no single, commonly recognized framework for critically examining ideology in textbooks, there is no shortage of interdisciplinary studies that underscore textbooks as artifacts of interest in education. Critical Discourse Studies (CDS) investigations of textbooks have revealed them to be more than just materials or tools for learning. Rather, they are vehicles for certain social realities, values, or norms, positioned as preferable or desirable under the umbrella of education, that is unquestioned or unchallenged (Curdt-Christiansen \& Weninger, 2015; Macgilchrist, 2017). CDS surveys of textbooks not only underscore linguistic patterns but address visibility or representation, agency, dominant discourses, and hegemony (Macgilchrist, 2017).

These constructs not only materialize in linguistic components of textbooks, but also in various features and modes of multimodal discourse, such as images, graphs, charts, colours, and multimedia components, for example, audio and video, etc. These modes of meaning-making are collectively examined in multimodal analysis because while different modes have independent communicative potentials, they interact with one another in a field of meaning that projects an over-arching ideological construct (Jewitt et al., 2016). In other words, language is not the sole providence for communication because almost all interaction is multimodal and each mode, whether on its own or interactively, is sourced in ideological expression and motivated by social interests (Jewitt et al., 2016). Building on this literature, the present study assumes that within textbooks, such as those featured in the present study (for secondary and post-secondary institutions), discourses are often multimodal in their lessons, where image and text become indistinguishable from one another as singular amalgams of meaning-making (Bateman, 2014). 
Given the importance of textbooks in education and their role in engendering, maintaining and resisting certain ideologies in opaque multimodal discourses many scholars from different fields of inquiry have been investigating them for the past several decades (Macgilchrist, 2017). One of the most recent and productive research approaches to textbooks has been CDS. The present study conducts a review of literature that feature CDS investigations of textbooks, asking: 1) What are the most represented approaches of CDS used for examining textbooks? 2) What themes appear to draw the most attention? 3) In what fields of study are the examined textbooks situated? 4) How do these emergent themes appear to be connected? 5) What areas of research appear lacking in the collected literature? To seek answers to these questions, we build on Rogers et al. (2005) in a similar refinement of their discoveries.

In a review of their findings of CDS in education, Rogers et al. (2005) endeavoured to define this research approach, discover what frameworks were employed, and in what contexts CDS was chosen for investigative research. Rogers et al. (2005) point out that the importance of looking at CDS in education was partially driven by observations that criticality illuminates the implications of social practices and the unfair distribution of social commodities and power. The authors contend that in the contexts of education, especially in language learning, "language is a social practice and because not all social practices are created and treated equally, all analyses of language are inherently critical" (p. 367). Looking at five databases of articles featuring CDS research from 1980-2003, Rogers et al. (2005) found a common thread that problematized and identified "unintended consequences of educational decisions, policies, and social practices" (p. 383) in education. They further recommend continued research of CDS in education, pointing out that researchers should consider multimodal discourses in published materials.

In what follows, we will first present an overview of CDS, an overview of databases where the reviewed literature was drawn, the analytical procedures, inspired by Rogers et al. (2005) that highlights the contexts/topics, theoretical frameworks, analyzed data, method of analysis, findings, and implications of each study from the collection. Finally, we will underscore the most represented approaches of CDS, the fields of study in which they are situated, and what gaps in research appear in the reviewed literature.

\section{Critical Discourse Studies}

Until recent years CDS was commonly referred to as critical discourse analysis (CDA), which emerged out of Fairclough's Language and Power (1989). Constructs from several major thinkers have informed the theoretical and methodological underpinnings of CDS in the past forty years or so, for example, ideology from Althusser (2001), discourse and power from Foucault (2003), critical from the Frankfurt School (Wodak \& Meyer, 2015), hegemony from Gramsci (i.e., Gramsci \& Buttigieg, 1991), dialogism and by extension intertextuality from Bakhtin (1981), language as symbolic power from Bourdieu (1992), and language as social action from Halliday (1978).

Prior to Fairclough's Language and Power (1989), two seminal publications Language and Control (Fowler, et al., 1979) and Language as Ideology (Hodge \& Kress, 1993) which were devoted to establishing critical linguistics are often cited as precursors to CDS (Flowerdew \& Richardson, 2017; Rogers et al., 2005). Those publications likely played a key role in incentivizing linguistic scholars from myriad backgrounds to engage in 
rigorous investigations of language and society. In the years that have followed, Rogers et al. (2005) have reminded us that CDS emerged from interdisciplinary beginnings, seeded in scholarly research at separate institutions where social theory began weaving into linguistic investigation with "an attitude", as Kress (1993) put it. The sociology and linguistics interface had begun a few decades earlier, in the 1960s and 70s, with the emergence of sociolinguistics (Ball, 2012).

In a research tradition that attempts to unite theory of language to society, some are refracted, like light through a prism, appearing as different hues in their theoretical leanings (Flowerdew \& Richardson, 2017). Where Fairclough's (2013) DialecticalRelational Approach draws on Althusser, Foucault, Bourdieu, and Gramsci, at the macro level, and employ Systemic Functional Linguistics at the micro, descriptive level, Ruth Wodak's Discourse-Historical Approach mainly draws on Frankfurt School's critical social theories (Flowerdew \& Richardson, 2017), at the macro level, and on pragmatics, rhetoric and SFL at the micro-descriptive level. Despite the different methods and theories, all CDS research resonate a similar perspective that discourse affects society as much as society affects discourse (Flowerdew \& Richardson, 2017, p. 2). Other foundational approaches within CDS include Teun van Dijk's socio-cognitive approach, critical treatments and adaptations of Halliday's systemic functional linguistics (SFL), and Theo Van Leeuwen's social actors, among others (for an overview of these approaches see Flowerdew \& Richardson, 2017).

For Huckin (2002), CDS is unique for several reasons: a) it is not experienced in a vacuum but in a real-world context; b) it is open to integration between text, discursive practice, and social practice; c) it is concerned with societal issues; d) it requires the researcher to take an ethical stance in the process of analysis; e) supports a view that discourse is socially constructed; f) endeavours to be accessible to a broad, non-specialist audience (for more tenets of CDS see also Fairclough \& Wodak, 1997; Van Dijk, 2011). Other scholars have also underlined the ideological nature of discourse and how it is an indispensable part of power relations (i.e., Van Dijk, 1993; Wodak \& Meyer, 2015). Bearing these tenets in mind, it is not surprising that CDS attracted researchers of education and textbooks (in particular) because no textbook, in any curriculum, is neutral in expressing, either implicitly or explicitly, a particular social order (Auerbach \& Burgess, 1985, p. 490). Additionally, the classrooms in which they are frequently used are social ecologies constantly in flux (Duff \& Van Lier, 1997; Kumaravadivelu, 1999) with the live negotiation of a textbook's content between students and their teachers (Littlejohn, 2012; Wohlwend, 2011).

While some of the literature appears to engage multimodal discourse by focusing on the visual transitivity in the representation of social actors (e.g., Fairclough, 1989) little connection is made with multimodal CDS, such as Kress and Van Leeuwen (2006) or Machin and Mayr (2012). In the term multimodality, a mode is a means for making meaning, such as speech, writing, image, sound, or colour, so multimodality refers to using multiple modes in the same piece of discourse (Kress \& Van Leeuwen, 2002). As with CDS, Kress (2010) admits there is no theory accounting for the present state of communication or how that might encapsulate multimodality, but consistency lies in the connection between semiotic resource and social construction. Thus far, we have seen that in Macgilchrist (2017), "critical approaches to textbook discourse have helped reconceptualize textbooks as cultural and political practices" (p. 525) and Rogers et al. 
(2005) has done this with CDS in education in general. Although Macgilchrist (2017) and Rogers et al. (2005) have shown us that textbooks contribute to the discursive construction of ideologies and power relations, they have not specified as to what approaches or methods of CDS have been most productive in studying textbooks, and what kinds of textbooks have received the most attention in research. In this paper, we aim to address both issues. Finally, we aim to illustrate that CDS not only identifies social injustice manifested in textbook content but challenges it and affects some drive towards change, for example, change in attitudes about the ideological nature of discourse through engendering critical language awareness in society (Fairclough, 1992; Van Dijk, 1993).

\section{Methods}

\section{Overview of Databases}

The literature reviewed in this study was drawn from three social science databases (JSTOR, SAGE, and ERIC) and cross-referenced with searches on Google Scholar and bibliographies from personal academic projects. Using the search terms "critical discourse analysis" or "critical discourse studies" + "textbooks", selected literature was further filtered to exclude non-peer reviewed literature. It should also be noted that by "textbook", the present study is referring to those texts used in secondary and post-secondary levels in public educational institutions. While most of the literature includes the term critical discourse analysis or critical discourse studies somewhere in the literature, some did not. Unlike Rogers et al. (2005), this study did not exclude articles where CDS, as a term, was absent. Despite a lack of explicitness, some appear to regard social practices through a lens of power relations and ideologies. In other words, research conducted towards revealing social unfairness in textbook content was deemed an acceptable digression because they remained within criteria for criticality in discourse analysis (Flowerdew \& Richardson, 2017).

\section{Analytical Procedure}

A categorical annotation chart, partially informed by Rogers et al. (2005), was developed to capture the context, research questions, theoretical frameworks, analyzed data, method of analysis, findings, thesis or assertions, and implications of each of the studies in the collection. Each of the articles were read and, as the table evolved, common themes, contexts (e.g., Ukrainian Social Studies, Chilean History), aims, purposes, research questions, textbook types investigated, findings and narratives of social realities were noted in the analyses, which we will discuss in the following sections. After completing the categorization chart, summary notes were added to those thematic observations during discovery to clearly delineate trends apparent in the literature. A few significant themes emerged from the data, additionally serving to indicate apparent gaps of research into which critical discourse analyses of textbooks had yet to venture. This study does not claim to have found all CDS investigations of textbooks, particularly those studies prior to 1999 . However, considering that critical investigations of textbooks (whether explicitly noting CDS or not) have risen in number in recent decades, the collected literature was deemed 
sufficient to indicate relevant patterns of discovery from which to infer the presence of emergent themes.

\section{Organization of the Reviewed Literature}

The findings of the review will be presented in the following sections. First, the findings will be generally summarized. Then, the emergent themes, as noted above, will be addressed, identifying relevant literature that appears to best represent findings aligned to those trends. Finally, the results are summarized in a discussion section, giving focused attention to the research questions answered by the literature reviewed in addition to indicating what future research might be undertaken for critical discourse analyses of textbooks.

\section{Findings}

The categorical annotations chart (we were unable to include it due to brevity) served as a descriptive overview of the findings from the 60 articles and theoretical studies of CDS and textbooks drawn from JSTOR, ERIC and SAGE publishing databases. The chart is organized to clearly cite the authors and publication, context of the study, theoretical frameworks informing the investigation, data, method of analysis or nonspecified critical analyses thereof, findings, and implications of that study. The chart informs us that while all articles reviewed included critical discourse analyses (either specified or otherwise) of textbooks, there was great diversity in many of the contexts, the textbooks analyzed, and what approaches were employed in those investigations.

The focus of many articles drew attention to potential social injustices in textbook content, including imbalanced gender representation, marginalized minorities or communities, national identity and citizenship, the development of child identity, anthropocentric agency, racism, Whiteness theory (see Table 1). Investigations of gender representation and marginalized minorities and/or communities collectively represent half of the total number of studies reviewed. All other contexts (identity, racism, etc.) collectively represented the other half of the reviewed literature.

Table 1

Themes in the Literature

Literature Reviewed $\quad \mathrm{N}=60$

Gender representation $38.4 \%$

Marginalized minorities or communities $19.1 \%$

Theoretical studies of CDS and textbooks $10.6 \%$

National Identity \& Citizenship $10.6 \%$

Development of child identity \& Values $8.5 \%$

Anthropocentric agency $4 \%$

Racism \& Whiteness theory $4 \%$

Misrepresentation of Curriculum $2 \%$ 
Collectively, the types of textbooks examined in the literature reviewed were as diverse as their contextual focus. However, some types of books clearly drew the lion's share of investigative attention. Figure 1 illustrates the variety of textbooks investigated in the reviewed literature and English as a Foreign Language (EFL) textbooks greatly outnumber the other studies.

\section{Figure 1}

Types of textbooks studied

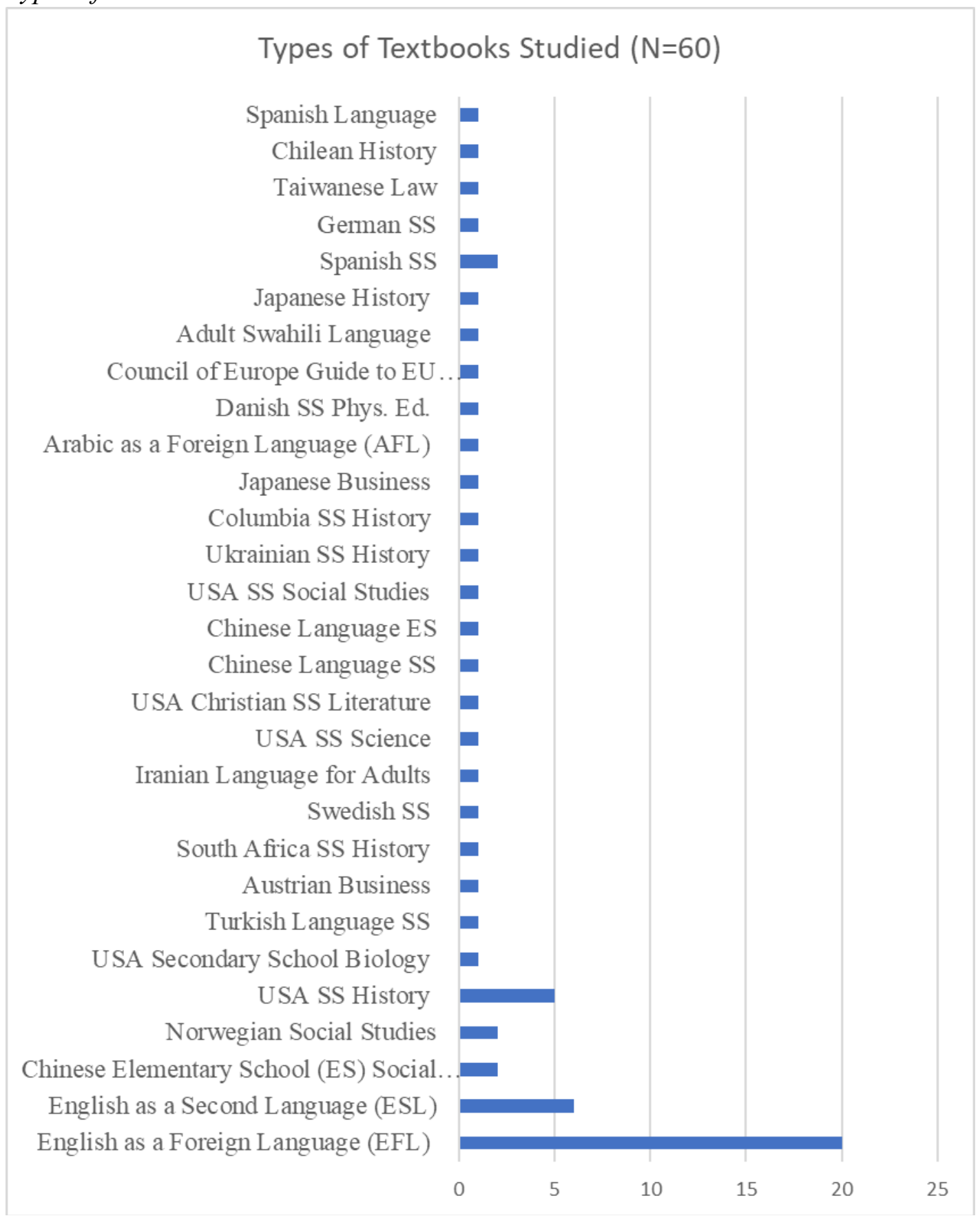


The employed frameworks, including those where investigations did not specify CDA but adhere to Gee's (2004) criteria for criticality in discourse are illustrated in Figure 1. While Fairclough $(1989,1992)$ was the most employed, content analysis (i.e., Sinclair \& Coulthard, 1992) or unspecified frameworks outnumbered some pioneering frameworks from scholars in the field, including Van Dijk (1993), Van Leeuwen (1996), Hodge and Kress (1993), Lemke (1989), Wodak and Meyer (2015), and Gee (2004).

Figure 2

Research Approach

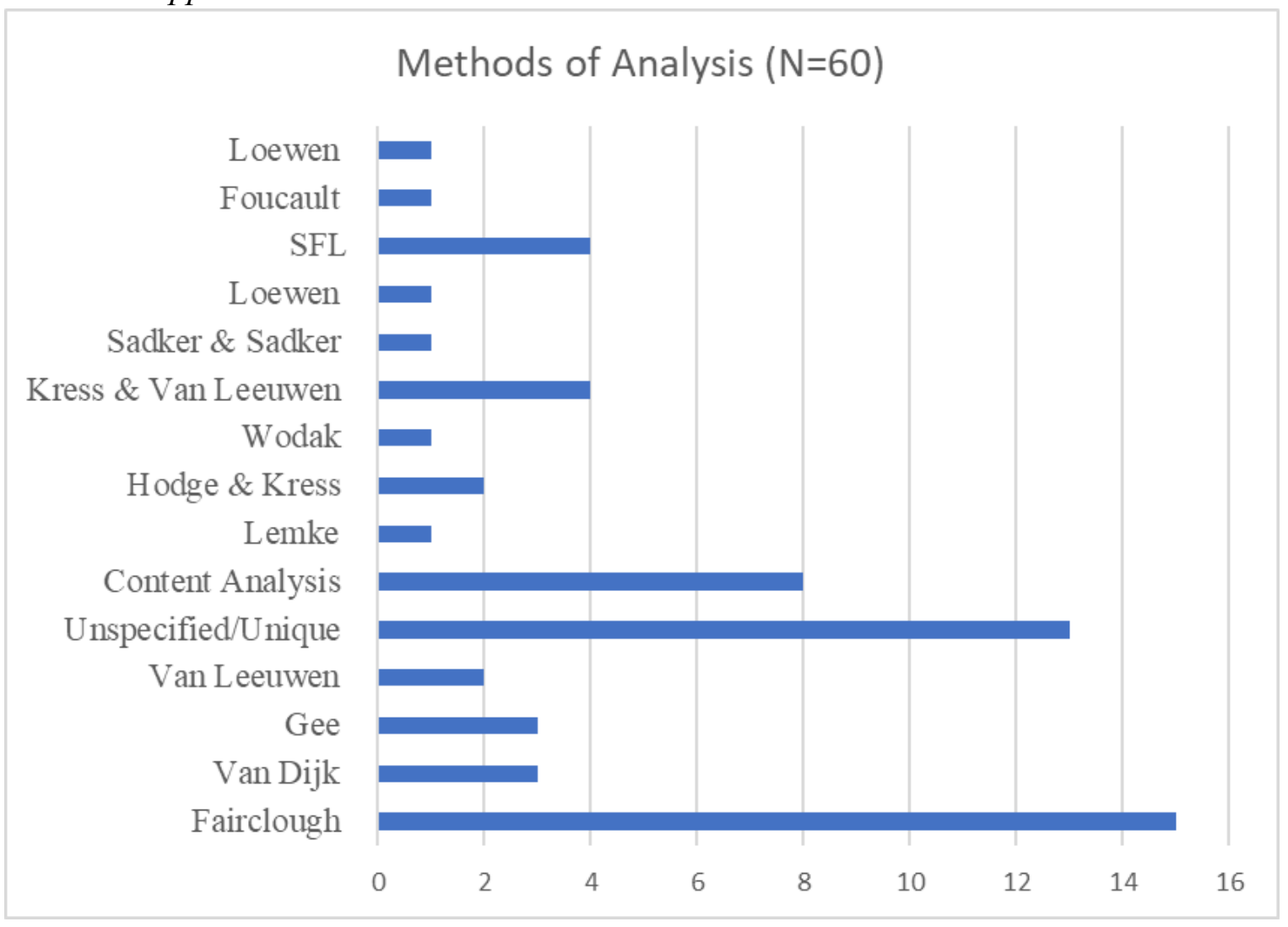

The following discussion explores emergent themes in the literature, highlighted by the findings, paying close attention to the fields of study in which those common investigations occur. After addressing the research questions, moving forward with these findings, the discussion will endeavour to postulate gaps in research areas in the collected studies. Those observations will serve to conclude this study and offer potential avenues for future research.

\section{Discussion}

The present study asked: 1) What are the most represented approaches of CDS used for examining textbooks? 2) What themes appear to draw the most attention? 3) In what fields of study are the examined textbooks situated? 4) How do these emergent themes appear to be connected? 5) What areas of research appear lacking in the collected 
literature? The following sub-sections address these questions and indicate the relevant literature, giving evidence to any posited assertions.

An obvious trend that stands out in the literature is the use of Fairclough's (1989, 1992) approach to CDA. Fairclough (1989) served to inform and reveal apparent social injustices in the textbook content of more than $32 \%$ of the forty-seven articles reviewed. Those studies investigated the lack of human agency in the context of Christian-based science and literary textbooks used in secondary schools (Agiro, 2012; Sharma \& Buxton, 2015), marginalized communities and identities such as the Sami in Norway (Eriksen, 2018) and the treatment of indigenous people in South African history textbooks (Maposa, 2015), the othering of immigrant voices in Canada (Gulliver, 2010), racism and 'whiteness' evident in humanities textbooks (Harper, 2012), nationalism (Vinall \& Shin, 2019), imbalanced gender representation where male social actors possess most or all forms of agency (Giaschi, 2000; Setyono, 2018), and membership criteria for citizenship (Ververi, 2017). Rising from these revealed social injustices, marginalized communities or identities and male dominance in gender representation are exposed in five of the fifteen articles in which Fairclough (1989) is utilized. Of those, three are studies of language learning textbooks, possibly foreshadowing a curiosity exposed in the findings: while Fairclough's approach (1989) is certainly the most represented approach for CDS in the literature reviewed, other frameworks are more strongly represented in the most common contextual focuses of textbooks.

In Table 1, the most common investigations appear to be motivated by a focus on gender representations, where the findings exposed males as the dominant social actors in all forms of discourse, including multimodal examinations (Ahour \& Zaferani, 2016; Giaschi, 2000; Gungor \& Prins, 2010; Healy, 2009; Lee, 2011; Marefat \& Marzban, 2014; Nofal \& Qawar, 2015; Sadeghi \& Maleki, 2016; Sahragard \& Davatgarzadeh, 2012; Setyono, 2018; Sherman, 2010; Soylemez, 2010; Stockdale, 2006; Tajeddin \& Janebi, 2010; Thomson \& Otsuji, 2003). This trend is closely followed by investigations of marginalized identities or communities, and othering (Van Dijk, 2011; Wodak \& Meyer, 2015). Van Dijk (2011) describes "othering" as the process by which discourse either sufficiently presents or omits information that divides or segregates a particular community or group as 'them' or, sometimes insidiously, as "not us" (Machin \& Mayr, 2012). These social injustices were exposed in studies of social conditioning (e.g., Chiu, 2011, Borhaug, 2014), where certain communities were marginalized in the content (Chu, 2015; Eriksen, 2018; Maposa, 2015; Song, 2013; Thompson, 2013; Xiong, 2012) or by “othering" certain groups as less important to national interests (Camase, 2009; Popson, 2001) or less important than an academic pursuit (Lee, 2011) or government immigration policies (Gulliver, 2010). A curiosity of these trends in the literature are the methods of analysis; while Fairclough (1992) is the most strongly represented approach to CDS across all literature, in this contextual category, content analyses of various, unspecified types or Wodak and Meyer (2015), or Gee (2004), or Van Dijk (1993), or Kress and Van Leeuwen $(1996,2006)$ are diversely represented. In other words, where many of the studies involved an examination of how gender or a group of people are "presented" or "not presented" (graphically and textually), there appear to be very few investigations that mention multimodality as a theoretical framework or in the methodologies but appear to utilize uniquely composed frameworks (e.g., Camase, 2009) with two or more CDS approaches. 
The textbook subjects that are most strongly represented in the literature are quite diverse (see Figure 1). However, it is obvious that textbooks for EFL (numbering 20/60 articles) are drawing the most critical attention. The literature of this study appears to give earnest attention to global EFL textbooks, widely published by British or American institutions (Harwood, 2014), such as Interchange (Richards et al., 1998) or the Top Notch series (Saslow \& Ascher, 2006). It may be that "global EFL textbooks" are deserving of scrutiny because of the "key role they play in many classrooms around the world" (Gray, 2010, p. 1).

In response to questions four and five, as to how these studies are connected and what approaches appear to be lacking in the selected literature, we can say that although they have been situated in a variety of fields and a diverse range of themes, they share some commonalities. One of the areas of research that seems to be neglected in our data is MCDS of textbooks. As noted in our introduction, textbooks of all types are rich with multimodal discourses in their lessons, where image and text become indistinguishable from one another as singular amalgams of meaning-making (Bateman, 2014). Certain studies, now obvious in their isolation from the other groupings in the literature reviewed, stand out as relevant examples of investigations featuring multimodal critical discourse analyses, even if that term is not explicitly referenced. Studies such as Gulliver and Thurrell (2017), Fitzgibbon (2013), and Pellegrino et al. (2013) underpin the presence of racism, Whiteness and the plight of African-Americans' portrayal in history, racism against Asians, and the representation of Canadian immigration, but they do not appear to sufficiently engage the contents in the textbooks with frameworks for multimodal critical discourse analysis (i.e., Machin \& Mayr, 2012). We are not suggesting that critical discourse studies of racism, for example, require a multimodal approach more than others, or that racism is not discursive, or that perceived social injustices are somehow based more on visual discursivity. On the contrary, multimodality is not the absence of considerations of text, but rather the inclusion of multiple modes of meaning making, such as visual devices (Jewitt et al., 2016). We are asserting that more multimodal considerations of textbook content and clearly defined analytical procedures are needed to uplift the current trajectories of research.

Furthermore, while studies such as Gulliver and Thurrell (2017), Fitzgibbon (2013), and Pellegrino et al. (2013), are certainly implying and underscoring social injustices in the multimodal discourses of their respective analyses, their methodologies feel incomplete. For an MCDS to achieve completeness and diminish perennial criticisms such as "cherrypicking" data (i.e., Widdowson, 2004), Jewitt et al (2016), remind us that "meaning is made with different semiotic resources, each offering distinct potentialities and limitations that involves the production of multimodal wholes, so we need to attend to all semiotic resources being used to make a complete whole" (p. 3). Acquiescing to Jewitt et al. (2016), we maintain that some of the studies mentioned here could benefit from employing explicit analytical steps to account for all the meaning-making potential in textbooks.

The lack of MCDS of textbooks, as noted by Curdt-Christiansen and Weninger (2015) and Gray (2010), regarding ELT textbooks, suggests an insufficiency and a sense of incomplete accountability. For example, Svendsen and Svendsen (2017), give critical attention to the interpretation of a particular series of physical education textbooks used in a curriculum; Osborn (2017), exposes the misrepresentation of Palestinian and Jewish relations in the use of agency that appears in experiments in science textbooks; Agiro 
(2012) examines textbooks published by Christian-led communities which diminish anthropocentric climate change while encouraging students to accept a lack of critical rhetoric; Vinall and Shin (2019) expose the rise of nationalism vs. international diversity; Liu (2005) reveals the social conditioning of youth in China, which urges conformity to certain social norms as prescribed by governmental policies. In short, each of these studies does not underscore an explicit critical multimodal discourse analysis in their theoretical frameworks or methods of analysis, even though their explorations are clearly multimodal.

\section{Conclusion}

The present study looked at peer-reviewed literature $(\mathrm{N}=60)$ drawn from three scholarly databases (JSTOR, ERIC, and SAGE; cross-referenced with searches on Google Scholar) that use critical discourse analysis for those investigations. The most represented approaches to critical discourse analysis employed Fairclough (1989). The field of EFL textbooks far outweighed all other textbook types in terms of research attention. Within that research attention, the highest concentration of articles focused on imbalanced gender representation.

Many articles appeared to use novel methods of analysis, informed by various frameworks. Creating one's own framework or method of analysis (outside of a dissertation) may be suggestive of a lack of options from which to draw the right tool for the job. Perhaps researchers looking at textbooks for issues of gender representation felt hungry for an approach that served to inform and reveal all the social injustices those textbooks contained. In the case of EFL textbooks and the persistence of imbalanced gender representations, they appear to contain, this study recommends more focus on multimodal theoretical frameworks and investigations. Perhaps this suggestion may also serve to uncover more instances of social injustices in other studies that appear underrepresented in the literature, such as curricular misinformation, the social conditioning of children, racism, and the denial of anthropocentric climate change.

Looking at the most prominent representations of research approaches and contextual attention in the reviewed literature (studies of gender representation and marginalized/dominated communities in EFL textbooks), most surprising is the lack of multimodality in the literature and the diverse scholarly works that have been done to include it in CDS (i.e., Machin \& Mayr, 2012). In all the literature ( $N=60)$, while many studies gave earnest attention to how a community or group is presented, few studies gave sufficient attention to (or were theoretically informed by) any multimodal scholars outside of Kress and Van Leeuwen $(1996,2006)$. This apparent gap in research is accompanied by a significant absence of studies that triangulate analyses, as noted in the previous section. Therefore, richer harvests of findings in CDS await researchers to engage in multimodality and/or include multiple methods to corroborate findings from multiple perspectives, so that common criticisms may be mitigated, and social change inspired via rigorous analysis.

At a glance, textbooks may not be regarded as important as they once were, now that their niche includes more online teaching materials and components, but in further regard for the findings we have seen in the selected literature, textbooks have expanded in reach rather than diminished in their role as a curricular commonplace because the world once read now includes the world seen (Kress, 2010). In other words, the multimodal discourse in all the multimedia components included in a textbook publication potentially 
increases the alacrity and potency of the educational program. For this reason, we call for more studies of the affordances of contemporary textbook publications to measure their multimodality, value, and efficacy in 21 st-century learning. In particular, the present study has shown that in English language learning contexts, textbooks have not lost value in their educational currency and the multimodal engagements included in those publications should continue to draw the attention of CDS.

Correspondence should be addressed to Christopher Smith.

Email: christophersmith5@cunet.carleton.ca

\section{References}

Agiro, C. P. (2012). Comparative critical discourse analysis of student and teacher editions of secondary Christian American literature textbooks. Journal of Research on Christian Education, 21(3), 211-234. http://doi.org/10.1080/10656219.2012.733557

Ahour, T., \& Zaferani, P. (2016). A critical visual analysis of gender representation of ELT materials from a multimodal perspective. The Journal of Applied Linguistics, 9(18), 78-98.

Althusser, L. (2001). Lenin and philosophy and other essays. Monthly Review Press.

Auerbach, E. R., \& Burgess, D. (1985). The hidden curriculum of survival ESL. TESOL Quarterly, 19(3), 475-495.

Bakhtin, M. M. (1981). The dialogic imagination. University of Texas Press.

Ball, S. J. (2012). Foucault, power, and education. Routledge.

Bateman, J. (2014). Text and image: A critical introduction to the visual/verbal divide. Routledge.

Børhaug, K. (2014). Selective critical thinking: A textbook analysis of education for critical thinking in Norwegian social studies. Policy Futures in Education, 12(3), 431-444. http://doi.org/10.2304/pfie.2014.12.3.431

Bourdieu, P. (1973). Knowledge, education, and cultural change. Routledge.

Bourdieu, P. (1992). Thinking about limits. Theory, Culture \& Society, 9(1), 37-49.

Camase, G. (2009). The ideological construction of a second reality: A critical analysis of a Romanian EFL textbook [Master's thesis, University of Toronto]. http://hdl.handle.net/1807/18099 .

Canagarajah, A. S. (1993). Critical ethnography of a Sri Lankan classroom: Ambiguities in student opposition to reproduction through ESOL. TESOL Quarterly, 27(4), 601626. http://doi.org/10.2307/3587398

Chiu, L. Y. L. (2011). The construction of the "ideal Chinese child": A critical analysis of textbooks for Chinese heritage language learners [Doctoral Dissertation, University of British Columbia]. http://doi.org/10.14288/1.0072083

Chu, Y. (2015). The power of knowledge: A critical analysis of the depiction of ethnic minorities in China's elementary textbooks. Race, Ethnicity and Education, 18(4), 469-487. http://doi.org/10.1080/13613324.2015.1013460

Curdt-Christiansen, X. L., \& Weninger, C. (Eds.). (2015). Language, ideology and education: The politics of textbooks in language education. Routledge. 
Duff, P. A., \& Van Lier, L. E. O. (1997). Approaches to observation in classroom research: Observation from an ecological perspective. TESOL Quarterly, 31(4), 783-787. http://doi.org/10.2307/3587762

Eriksen, K. G. (2018). Teaching about the Other in Primary Level Social Studies: The Sami in Norwegian Textbooks. Journal of Social Science Education, 17(2), 57-67. http://doi.org/ 10.4119/jsse-875

Fairclough, N. (1989). Language and power. Longman.

Fairclough, N. (1992). Discourse and social change. Polity Press.

Fairclough, N. (2013). Critical discourse analysis: The critical study of language. Routledge. http://doi.org/10.4324/9781315834368

Fairclough, N., \& Wodak, R. (1997). Critical discourse analysis. In T. A. Van Dijk (Ed.), Discourse as social interaction (pp. 258-284). Sage.

Fitzgibbon, L. (2013). Ideologies and power relations in a global commercial English language textbook used in South Korean universities: A critical image analysis and a critical discourse analysis [Unpublished doctoral dissertation]. University of Queensland.

Flowerdew, J., \& Richardson, J. E. (Eds.). (2017). The Routledge handbook of critical discourse studies. Taylor \& Francis.

Foucault, M. (2003). Society must be defended: Lectures at the Collège de France, 197576. Picador.

Fowler, R., Hodge, B., Kress, G., \& Trew, T. (1979). Language and control. Routledge and Kegan Paul.

Fuchs, E., \& Bock, A. (Eds.) (2018). The Palgrave handbook of textbook studies. Palgrave Macmillan.

Gee, J. P. (2004). An introduction to discourse analysis: Theory and method. Routledge. http://doi.org/10.4324/9780203005675

Giaschi, P. (2000). Gender positioning in education: A critical image analysis of ESL texts. TESL Canada Journal, 18(1), 32-46. http://doi.org/10.18806/tesl.v18i1.898

Giroux, H. A. (1988). Teachers as intellectuals: Toward a critical pedagogy of learning. Greenwood Publishing Group.

Gramsci, A., \& Buttigieg, J. (1991). Prison notebooks. Columbia University Press.

Gray, J. (2010). The construction of English: Culture, consumerism and promotion in the ELT global coursebook. Springer.

Gulliver, T. (2010). Immigrant success stories in ESL textbooks. TESOL Quarterly, 44(4), 725-745. http://doi.org/10.5054/tq.2010.235994

Gulliver, T., \& Thurrell, K. (2017). Denials of racism in Canadian English language textbooks. TESL Canada Journal, 33, 42-61. http://doi.org/10.18806/tesl.v33i0.1245

Gungor, R., \& Prins, E. (2010). Reproducing gender inequality: A critical discourse analysis of a Turkish adult literacy textbook. Adult Education Research Conference. https://newprairiepress.org/aerc/2010/papers/27

Halliday, M. A. K. (1978). Language as social semiotic: The social interpretation of language and meaning. Hodder Arnold.

Harper, K. C. (2012). Decolonizing education: A critical discourse analysis of postsecondary humanities textbooks [Doctoral Dissertation, East Carolina University]. http://hdl.handle.net/10342/4071 
Harwood, N. (Ed.). (2014). English language teaching textbooks: content, consumption, production. Palgrave Macmillan.

Healy, D. (2009). The representation of women and men in a modern EFL textbook: Are popular textbooks gender biased. Memoirs of the Osaka Institute of Technology, Series B, 54(2), 91-100.

Hodge, R., \& Kress, G. (1993). Language as ideology. (2 ${ }^{\text {nd }}$ ed.). Routledge.

Huckin, T. (2002). Critical discourse analysis and the discourse of condescension. In E. Barton \& G. Stygall (Eds.), Discourse studies in composition (pp. 155-176). Hampton.

Jewitt, C., Bezemer, J., \& O'Halloran, K. (2016). Introducing multimodality. Routledge. http://doi.org/10.4324/9781315638027

Kress, G. (1993). Against arbitrariness: The social production of the sign as a foundational issue in critical discourse analysis. Discourse \& Society, 4(2), 169-191. http://doi.org/10.1177/0957926593004002003

Kress, G. (2010). Multimodality: A social semiotic approach to contemporary communication. Routledge. http://doi.org/10.4324/9780203970034

Kress, G. R., \& Van Leeuwen, T. (1996). Reading images: The grammar of visual design. Psychology Press.

Kress, G., \& Van Leeuwen, T. (2002). Colour as a semiotic mode: Notes for a grammar of colour. Visual communication, 1(3), 343368.http://doi.org/10.1177/147035720200100306

Kress, G., \& Van Leeuwen, T. (2006). Reading images: The grammar of visual design. Routledge.

Kubota, R., \& Lin, A. (2006). Race and TESOL: Introduction to concepts and theories. TESOL Quarterly, 40(3), 471-493. http://doi.org/10.2307/40264540

Kumaravadivelu, B. (1999). Critical classroom discourse analysis. TESOL Quarterly, 33(3), 453-484. http://doi.org/10.2307/3587674

Lee, I. (2011). Situated globalization and racism: An analysis of Korean high school EFL textbooks. Language and Literacy, 11(1). https://doi.org/10.20360/G2F59N

Lemke, J. L. (1989). Using language in the classroom. Oxford University Press.

Littlejohn, A. (1992). Why are English language teaching materials the way they are? [Unpublished doctoral dissertation]. Lancaster University.

Littlejohn, A. (2012). Language teaching materials and the (very) big picture. Electronic Journal of Foreign Language Teaching, 9(1), 283-297.

Liu, Y. (2005). The construction of cultural values and beliefs in Chinese language textbooks: A critical discourse analysis. Discourse: Studies in the Cultural Politics of Education, 26(1), 15-30. http://doi.org/10.1080/01596300500039716

Macgilchrist, F. (2017). Textbooks. In J. Flowerdew \& J. Richardson (Eds.), Routledge handbook of critical discourse studies (pp. 525-539). Routledge.

Machin, D., \& Mayr, A. (2012). How to do critical discourse analysis: A multimodal introduction. Sage.

Maposa, M. T. (2015). Reflections on applying critical discourse analysis methodologies in analysing South African history textbooks. Yesterday and Today, (14), 58-75. http://dx.doi.org/10.17159/2223-0386/2015/n14a3 
Marefat, F., \& Marzban, S. (2014). Multimodal analysis of gender representation in ELT textbooks: Reader's perceptions. Procedia-Social and Behavioral Sciences, 98, 1093-1099. http://doi.org/10.1016/j.sbspro.2014.03.521

Nofal, M. Y., \& Qawar, H. A. (2015). Gender representation in English language textbooks: Action pack 10. American Journal of Educational Science, 1(2), 14-18.

Ooiwa-Yoshizawa, A. (2012). Implications of EFL critical pedagogy: Theory, practice, and possibilities. Keiwa Bulletin, 21, 21-30.

Osborn, D. (2017). Constructing Israeli and Palestinian identity: A multimodal critical discourse analysis of world history textbooks and teacher discourse. Journal of International Social Studies, 7(1), 4-33.

Pellegrino, A., Mann, L., \& Russell III, W. B. (2013). To lift as we climb: A textbook analysis of the segregated school experience. The High School Journal, 96(03), 209-231.

Popson, N. (2001). The Ukrainian history textbook: Introducing children to the "Ukrainian nation". Nationalities Papers, 29(2), 325-350. http://doi.org/10.1080/00905990120053764

Richards, J. C., Hull, J., \& Proctor, S. (1998). New interchange - student book 3: English for international communication. Cambridge University Press.

Rogers, R., Malancharuvil-Berkes, E., Mosley, M., Hui, D., \& Joseph, G. O. G. (2005). Critical discourse analysis in education: A review of the literature. Review of Educational Research, 75(3), 365-416.

Sadeghi, B., \& Maleki, G. (2016). The representation of male and female social actors in the ILI English series. Journal of Language Teaching and Research, 7(2), 307-317. http://doi.org/10.17507/j1tr.0702.09

Sahragard, R., \& Davatgarzadeh, G. (2012). The representation of social actors in Interchange Third Edition series: A critical discourse analysis. Journal of Teaching Language Skills, 29(1), 67-89. http://doi.org/10.22099/JTLS.2012.401

Saslow, J. M., \& Ascher, A. (2006). Top Notch: Student book. Pearson Longman.

Setyono, B. (2018). The portrayal of women in nationally-endorsed English as a foreign language (EFL) textbooks for senior high school students in Indonesia. Sexuality \& Culture, 1-17. http://doi.org/10.1007/s12119-018-9526-2

Sharma, A., \& Buxton, C. A. (2015). Human-nature relationships in school Science: A critical discourse analysis of a middle-grade science textbook. Science Education, 99(2), 260-281. http://doi.org/10.1002/sce.21147

Sharp, R., Green, A., \& Lewis, J. (2017). Education and social control: A study in progressive primary education. Routledge.

Sherman, J. E. (2010). Multiple levels of cultural bias in TESOL course books. RELC, 41(3), 267-281. http://doi.org/10.1177/0033688210380576

Shor, I. (1992). Culture wars: School and society in the conservative restoration. University of Chicago Press.

Sinclair, J., \& Coulthard, M. (1992). Towards an analysis of discourse. In M. Coulthard (Ed.), Advances in spoken discourse analysis (pp. 1-34). Routledge.

Song, H. (2013). Deconstruction of cultural dominance in Korean EFL textbooks. Intercultural Education, 24(4), 382-390. http://doi.org/10.1080/14675986.2013.809248 
Söylemez, A. S. (2010). A study on how social gender identity is constructed in EFL coursebooks. Procedia-Social and Behavioral Sciences, 9, 747-752. http://doi.org/10.1016/j.sbspro.2010.12.228

Stockdale, A. D. (2006). Gender representation in an EFL textbook [Unpublished Master's thesis]. University of Birmingham. https://www.birmingham.ac.uk/documents/collegeartslaw/cels/essays/sociolinguistics/dastockdale-sociolinguistics.pdf

Svendsen, A. M., \& Svendsen, J. T. (2017). Contesting discourses about physical education. European Physical Education Review, 23(4), 480-498. http://doi.org/10.1177/1356336X16657279

Tajeddin, Z., \& Janebi, E. M. (2010). Gender representation and stereotyping in ELT textbooks: A critical image analysis. TELL, 4(2), 51-79. Doi: 10.22132/TEL.2010.66107

Thoma, M. (2017). Critical analysis of textbooks: knowledge-generating logics and the emerging image of 'global economic contexts'. Critical Studies in Education, 58(1), 19-35. http://doi.org/10.1080/17508487.2015.1111248

Thompson, K. D. (2013). Representing language, culture, and language users in textbooks: A critical approach to Swahili multiculturalism. The Modern Language Journal, 97(4), 947-964. http://doi.org/10.1111/j.1540-4781.2013.12047.x

Thomson, C. K., \& Otsuji, E. (2003). Evaluation of business Japanese textbooks: Issues of gender. Japanese Studies, 23(2), 185-203. http://doi.org/10.1080/1037139032000129711

Van Leeuwen, T. (1996). The representation of social actors in discourse. In CaldasCoulthard, C. R., \& Coulthard, M. (Eds.), Texts and practices: Readings in critical discourse analysis (pp. 32-70). Routledge.

Van Dijk, T. A. (1993). Principles of critical discourse analysis. Discourse \& Society, 4(2), 249-283. http://doi.org/10.1177/0957926593004002006

Van Dijk, T. A. (Ed.). (2011). Discourse studies: A multidisciplinary introduction. Sage.

Ververi, O. (2017). The Council of Europe's citizenship conception in 'Education for Democratic Citizenship': a critical discourse analysis of two textbooks. Globalisation, Societies and Education, 15(4), 518-530. http://doi.org/10.1080/14767724.2017.1335594

Vinall, K., \& Shin, J. (2019). The construction of the tourist gaze in English textbooks in South Korea: exploring the tensions between internationalisation and nationalisation. Language, Culture and Curriculum, 32(2), 173-190.

Vološinov, V. N. (1973). Marxism and the philosophy of language. Harvard University Press.

Wodak, R., \& Meyer, M. (Eds.). (2015). Methods of critical discourse studies. Sage.

Wohlwend, K. E. (2011). Mapping modes in children's play and design: An actionoriented approach to critical multimodal analysis. In R. Rogers (Ed.), An introduction to critical discourse analysis in education (pp. 242-266). Routledge. 
Xiong, T. (2012). Essence or practice? Conflicting cultural values in Chinese EFL textbooks: A discourse approach. Discourse: Studies in the Cultural Politics of Education, 33(4), 499-516. http://doi.org/10.1080/01596306.2012.692958

Youdell, D. (2006). Subjectivation and performative politics-Butler thinking Althusser and Foucault: intelligibility, agency and the raced-nationed-religioned subjects of education. British Journal of Sociology of Education, 27(4), 511-52. 